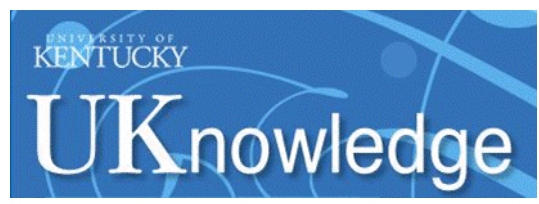

University of Kentucky

UKnowledge

\title{
THE EFFECTS OF A 16-WEEK INTRODUCTORY NUTRITION COURSE ON DIETARY HABITS AND BODY COMPOSITION OF COLLEGE STUDENTS
}

\author{
Emily Ashton \\ University of Kentucky, eeas223@g.uky.edu \\ Digital Object Identifier: https://doi.org/10.13023/ETD.2017.507
}

Right click to open a feedback form in a new tab to let us know how this document benefits you.

\section{Recommended Citation}

Ashton, Emily, "THE EFFECTS OF A 16-WEEK INTRODUCTORY NUTRITION COURSE ON DIETARY HABITS AND BODY COMPOSITION OF COLLEGE STUDENTS" (2017). Theses and Dissertations--Dietetics and Human Nutrition. 58.

https://uknowledge.uky.edu/foodsci_etds/58

This Master's Thesis is brought to you for free and open access by the Dietetics and Human Nutrition at UKnowledge. It has been accepted for inclusion in Theses and Dissertations--Dietetics and Human Nutrition by an authorized administrator of UKnowledge. For more information, please contact UKnowledge@lsv.uky.edu. 


\section{STUDENT AGREEMENT:}

I represent that my thesis or dissertation and abstract are my original work. Proper attribution has been given to all outside sources. I understand that I am solely responsible for obtaining any needed copyright permissions. I have obtained needed written permission statement(s) from the owner(s) of each third-party copyrighted matter to be included in my work, allowing electronic distribution (if such use is not permitted by the fair use doctrine) which will be submitted to UKnowledge as Additional File.

I hereby grant to The University of Kentucky and its agents the irrevocable, non-exclusive, and royalty-free license to archive and make accessible my work in whole or in part in all forms of media, now or hereafter known. I agree that the document mentioned above may be made available immediately for worldwide access unless an embargo applies.

I retain all other ownership rights to the copyright of my work. I also retain the right to use in future works (such as articles or books) all or part of my work. I understand that I am free to register the copyright to my work.

\section{REVIEW, APPROVAL AND ACCEPTANCE}

The document mentioned above has been reviewed and accepted by the student's advisor, on behalf of the advisory committee, and by the Director of Graduate Studies (DGS), on behalf of the program; we verify that this is the final, approved version of the student's thesis including all changes required by the advisory committee. The undersigned agree to abide by the statements above.

Emily Ashton, Student

Dr. Tammy Stephenson, Major Professor Dr. Sandra Bastin, Director of Graduate Studies 
THE EFFECTS OF A 16-WEEK INTRODUCTORY NUTRITION COURSE ON DIETARY HABITS AND BODY COMPOSITION OF COLLEGE STUDENTS

\section{THESIS}

A thesis submitted in partial fulfillment of the requirements for the degree of Master of Science in Nutrition and Food Systems in the College of Agriculture, Food and Environment at the University of Kentucky

\section{By}

Emily Ashton, RDN, LD

Lexington, Kentucky

Director: Dr. Tammy Stephenson, Ph.D.

Lexington, Kentucky

2017

Copyright (C) Emily Ashton 2017 


\section{ABSTRACT OF THESIS}

\section{THE EFFECTS OF A 16-WEEK INTRODUCTORY NUTRITION COURSE ON DIETARY HABITS AND BODY COMPOSITION OF COLLEGE STUDENTS}

As the rates of obesity continue to increase among adolescents and young adults, adopting healthy dietary and lifestyle habits is necessary in order to prevent obesity-related chronic disease later in life. Although several studies have addressed nutrition education and its effect on weight in college students, few studies have assessed percent fat as it relates to a semester-long nutrition course. As such, the effectiveness of a formal introductory nutrition course on lifestyle habits and percent fat of college students was examined. The current study aimed to address the relationship between percent body fat and nutrition education over the course of 8-months. Using a quasi-experimental design, this study compared changes among an intervention group and a comparison group presemester, post-semester and at 8-months follow-up. Participants completed a dietary habits survey and body composition was measured between August 2015 and May 2016. Results indicated that nutrition knowledge may have a short-term impact on dietary habits and body fat percentage among college-aged students. Between baseline and 4-months, we found a $1.9 \%$ reduction $(27.29 \%-26.77 \%)$ in body fat percentage among the experimental group, while there was a $2.5 \%$ increase $(25.25 \%$ - $25.89 \%)$ in body fat percentage among the control group. Although we could not determine the exact reason, our results suggest that the reduction in body fat percentage may be due to knowledge and exercise. Our findings suggest that nutrition education has the potential to affect body composition among college students.

KEYWORDS: obesity, college students, dietary habits, body composition, knowledge

Emily Ashton, RDN, LD

$11 / 17 / 2017$ 


\section{THE EFFECTS OF A 16-WEEK INTRODUCTORY NUTRITION COURSE ON DIETARY HABITS AND BODY COMPOSITION OF COLLEGE STUDENTS}

By: Emily Ashton, RDN, LD

Tammy Stephenson, $\mathrm{PhD}$

Director of Thesis

Sandra Bastin, PhD, RD, LD

Interim Director of Graduate Studies

November 17, 2017

Date 


\section{ACKNOWLEDGEMENTS}

This project would not have been possible without the tremendous support of my committee chair, Dr. Tammy Stephenson. Thank you for your guidance, patience, and encouragement in bringing my ideas to fruition. I am grateful to have had the opportunity to learn from and work with Dr. Stephenson and I could not have asked for a better mentor. I would also like to extend my appreciation to Dr. Dawn Brewer, Dr. Sandra Bastin, and Aaron Schwartz for taking an interest in my work and supporting me along the way. A special thanks to John Flunker, who worked with me to complete my statistical analyses.

Last but not least, I'd like to thank my family and friends for holding me to a high standard of achievement. Thank you for your support and for always motivating me to push my limits. 


\section{TABLE OF CONTENTS}

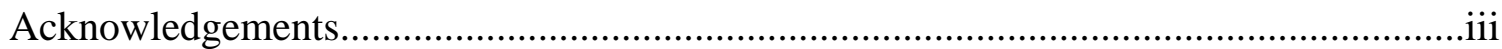

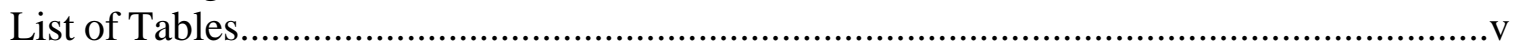

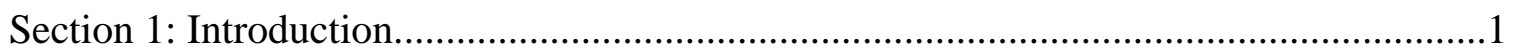

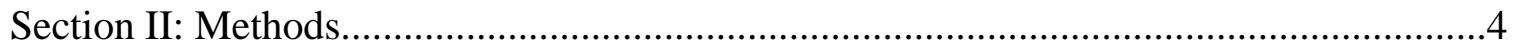

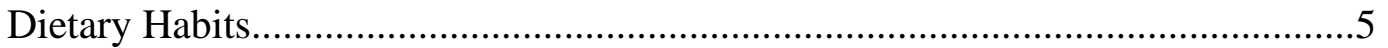

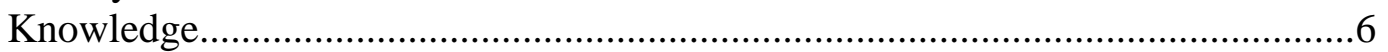

Motivation................................................................................................

Exercise and Physical Activity..................................................................... 7

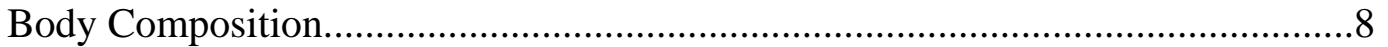

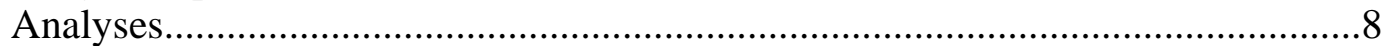

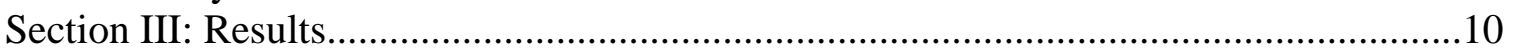

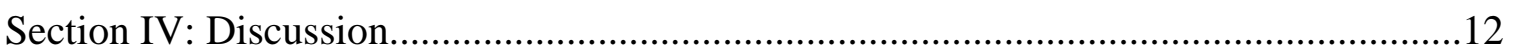

Appendix

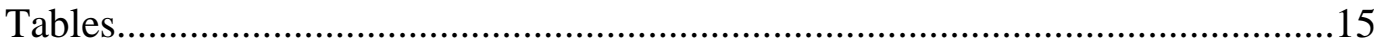

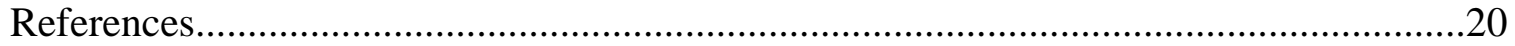

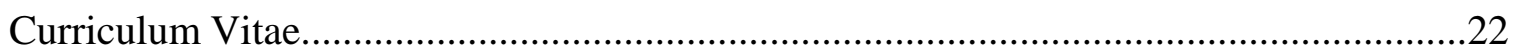




\section{LIST OF TABLES}

Table 1: Demographics of Study Population at Baseline................................................15

Table 2: Descriptive Statistics at Baseline..................................................................15

Table 3: Descriptive Statistics at 4-months...............................................................16

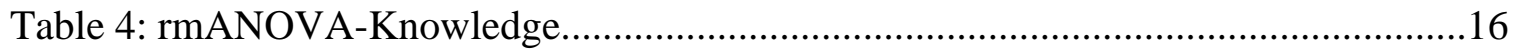

Table 5: rmANOVA-Exercise and Physical Activity.................................................16

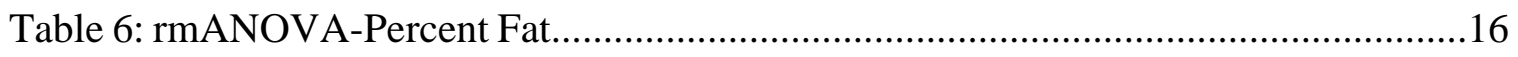

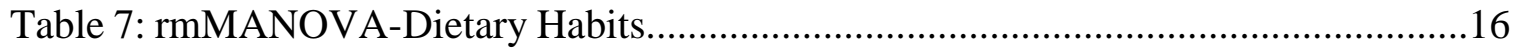

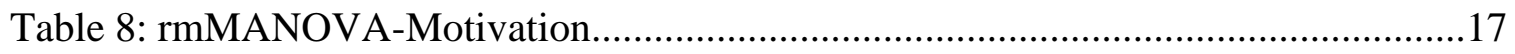

Table 9: Multiple Linear Regression at 4-months.....................................................17

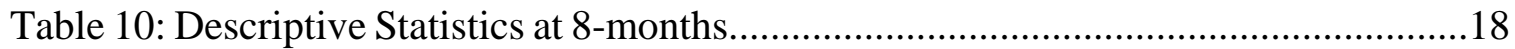

Table 11: T-Test-Knowledge, Percent Fat, and Exercise and Physical Activity................18

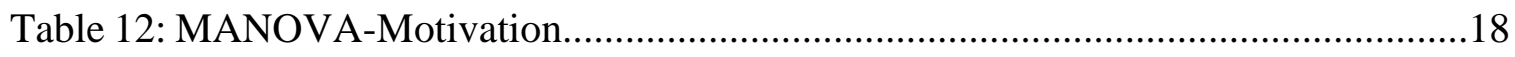

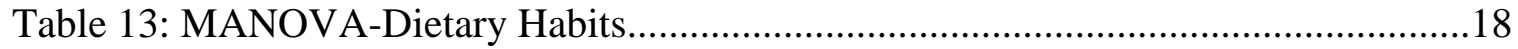

Table 14: Multiple Linear Regression at 8-months.....................................................19 


\section{$\underline{\text { Section 1: Introduction }}$}

The transition from adolescence to adulthood is an important time for health promotion and disease prevention (Nelson et al. 2008). Although nutrition education is widely used to promote healthy lifestyle choices in children and adolescents, it is rarely implemented for college students (Lin and Dali, 2011). As college students develop autonomy in their food choices, many struggle with eating a healthful diet in college (Clusky and Grobe, 2009). As such, many college students often experience weight gain due to poor dietary and lifestyle choices (Clusky and Grobe, 2009., Hull et al. 2007., Schweitzer et al. 2016).

Students attending college have been shown to gain significantly more weight than individuals of similar age who do not attend college (de Vos et al., 2015). For college-age students, weight gain exists not only during the first year but also throughout the course of the traditional four years of undergraduate education (Gropper et al. 2012). According to the National College and Health Assessment II survey, 31.3\% of college females and 34.6\% of college males are overweight or obese (American College Health Association, 2014). As such, BMI is the most frequently used method of assessing overweightness and obesity in general populations (Liu et al., 2013). However, percent body fat is a more accurate way to assess body fat and fat-free mass because BMI does not reflect true body fatness due to the fact that it only accounts for an individual's height and weight (Liu et al., 2013). There is strong evidence to support overweight and obesity associated with metabolic syndrome, cardiovascular disease, and Type 2 Diabetes (Mokdad et al., 2001). Because college students are gaining weight at six times the rate of the general population 
(Small et al., 2012), effective strategies to influence healthy behavior changes are necessary.

Poor dietary habits such as unhealthy dieting, meal skipping, fast food consumption and poor food choices are common among college students (Lua and Elena, 2012). Tam and colleagues found that items on campus such as cakes, muffins, and potato chips, items regularly available on many college campuses, were most frequently purchased by students (Tam et al. 2017). As well, the most commonly consumed snack foods, including chips, cookies, ice cream, and cupcakes, were correlated with lack of knowledge and limited finances (Downes, 2015). Similarly, 50\% of college freshmen report eating high-fat fast foods three or more times per week with consistent intakes continuing into sophomore year (Gonzales, et al., 2017). According to the 2015-2020 Dietary Guidelines for Americans (DGA), males and females ages 19-30 fall below the recommended guidelines for fruit, vegetables and dairy (DGA 2015). According to Racette and colleagues, only $1.3 \%$ of students met the recommended daily vegetable servings (Racette et al., 2005). In a sample of 106 college students, it was determined that $16 \%$ of students reported eating fruit daily, and only $17 \%$ of students ate green salad daily (Downes 2015). Although the DGA recommends $50 \%$ of total grain intake come from whole grains, only $13 \%$ of the college population is meeting this recommendation (Rose et al., 2007). As well, college students consume only 1.4 servings per day of low-fat or non-fat dairy, less than the DGA recommended three cup equivalents per day (Poddar et al., 2009).

The effectiveness of a formal introductory nutrition course on lifestyle habits of college students was examined at a large public university. While current literature suggests there are several options of nutrition education interventions, their effectiveness 
on improving eating habits and healthy lifestyle behaviors is unclear (Lin and Dali, 2011). Furthermore, studies similar to this have observed changes in Body Mass Index (BMI) and weight associated with nutrition interventions, but few have assessed body fat percentage as it relates to a semester-long nutrition course. As well, previous research largely focuses on freshman weight change and dietary behavior, yet there is little research examining weight changes and diet during the second and third year of college. The goals of this study were to evaluate the impact of a semester-long introductory nutrition course on nutrition knowledge, dietary choices, and body composition in college students at the end of the course (4-months) and at 8-months follow-up. 


\section{$\underline{\text { Section II: Methods }}$}

Students enrolled at the University of Kentucky between the ages of 18-24 were recruited for this study. Students in the experimental group were enrolled in an Introductory Nutrition during the Fall 2015 semester. Most students in the course were in health-related majors including nursing, pre-medicine, pre-physician assistant studies, pre-dental, and dietetics. All students enrolled in the course (approximately 180 students) had the opportunity to participate in this study. Participants were recruited through an in-class announcement and Blackboard post and the first 30 volunteers were accepted. Control group participants were recruited through listserv announcements and in-class announcements with professor approval in non-health related upper-level courses also offered through the College of Agriculture, Food, and Environment. The first 30 volunteers were also accepted to the study. There were no exclusions for ethnic backgrounds, however, participants were English-speaking. Additionally, students who have taken a nutrition class prior to the Fall 2015 semester were excluded from the comparison group.

The study lasted approximately two semesters (eight months), from the beginning of the Fall 2015 semester to the end of the Spring 2016 semester. All participants completed a dietary habits and health behaviors survey and had body composition assessed at three separate time points (August 2015, December 2015, May 2016). Students received incentives for completing the surveys and having body composition measured. The incentives were extra credit at the end of the first semester (4-months), and \$30 for the final data collection at 8-months. All study participants signed a consent form prior to all data collection in August 2015. The study procedures were approved by the University of Kentucky Non-Medical Institutional Review Board. 


\section{Dietary Habits}

The dietary habits and health behaviors survey was adapted from a validated National Health and Nutritional Examination Survey (NHANES) Food Frequency Questionnaire as well as the World Health Organization (WHO) Physical Activity Questionnaire, and consisted of 65 questions. The validity and reliability of the dietary habits survey does not exist. To measure these variables, a sum score was created by adding the total responses. Dietary habits were summed into five categories based on a number of questions:

Dairy- "How often do you drink milk as a beverage (NOT in coffee or cereal)?", "What type of milk did you usually drink?", "How often did you eat cheese?", "How often was the cheese you ate low-fat or light cheese?", "How often did you eat dairy products such as yogurt?" and "How often were the dairy products you ate low-fat or fat-free?".

Grains- "How often did you eat cold cereal?", "How often was the cold cereal you ate a whole grain type?", "How often did you eat rice or other cooked grains?", "How often did you eat pasta, spaghetti or other noodles?", "How often was the pasta you ate a whole grain type?", "How often did you eat sandwich bread?", "How often was the sandwich bread you ate whole wheat or whole grain?".

Fruits and Vegetables- "How often did you eat fruit?", "How often did you eat vegetables?", "How often were the lettuce salads you ate made with dark leafy greens?". Fat- "How often did you eat fried potato products such as French fries and hash browns?", "How often was the chicken you ate fried?", "How often did you eat mixed nuts?", "How 
often did you eat butter or margarine?", "How often did you eat mayonnaise?" and "How often were your vegetables cooked in some kind of animal fat?".

Protein- "How often did you eat red meat?", "How often did you eat chicken?".

Discretionary choices- "How often did you eat your breakfast from a package?", "How often did you drink soda?", "How often did you eat dessert?", and "How often did you eat frozen meals?".

Healthy Behaviors-"How often did you eat breakfast?", and "How often did you prepare your meals at home?"

Questions from the survey were coded based on frequency of consumption. For example, if the question stated, "How often do you drink milk as a beverage (NOT in coffee or cereal)?", responses could have been "never," "less than one time per week," "3-4 times per week," "5-6 times per week," "one time per day," or "two or more times per day". Depending on the frequency of consumption, responses were coded as "6" being 2 or more times per day, 5, 4, 3, 2, 1 through "0" indicating never. The 'healthier' frequencies, based on the DGA, were given the highest values, thus the sum scores would be higher based on how healthy the participant's intakes and choices were.

\section{Knowledge}

The knowledge group assessed four questions: "According to My Plate Guidelines, which of the following vegetables is considered the healthiest?", "According to My Plate Guidelines, which of the following protein sources is the healthiest?", "Which of the following grain choices has the most fiber?", and "According to the guidelines in the United 
States, healthy adults should engage in how many minutes of physical activity each week?". These questions provide an assessment of basic nutrition knowledge and are similar to those asked on exams in the course. Questions were coded as 1 if the participant answered correctly, and 0 if the participant answered incorrectly. These questions were then summed to create a summary knowledge score.

\section{Motivation}

The motivation category included three variables: autonomous motivation, controlled motivation, and amotivation. Motivation was calculated according a validated Dietary SelfRegulation survey (Williams et al., 1996). The survey was a 15-item scale that asked about the reasons why people would either start, or continue, to eat a healthier diet. Subsections of the scale were summed to create a summary score of the three types of motivation.

\section{Exercise and Physical Activity (PA)}

Exercise and PA were calculated based on two questions included in the dietary habits survey which were based on the WHO Physical Activity Questionnaire. Those questions were: "How long do you spend exercising per session?" and "How long do you spend walking to and from campus each day?". Responses could have been "I don't exercise/walk to and from campus," "less than 30 minutes,' "30-60 minutes," and "longer than 60 minutes". Responses were coded as 0 indicating the student does not walk to and from campus, 2 indicating less than 30 minutes, 3 indicating 30-60 minutes and 4 indicating longer than 60 minutes. The values of these two questions were summed. 


\section{Body Composition}

We chose body fat percentage for our analysis. We chose body fat percentage over BMI because BMI only accounts for height and weight and does not reflect true body fatness. Body fat percentage is a more accurate. The CosMed Bod Pod, using volume displacement, was used to measure the body composition of participants. Students were asked to wear tight fitting clothing such as spandex, or a swimsuit for females, and a swim cap. All jewelry and watches were removed.

\section{Analyses}

Data were analyzed using SPSS Statistics (Version 24) to investigate changes in dietary habits and body composition variables among groups over time. We grouped variables from our survey into five categories: knowledge (4 questions), percent fat, exercise and physical activity (2 questions), dietary habits (31 questions) and motivation (15 questions). A repeated measures ANOVA was used to look at changes in percent body fat, knowledge, and exercise and physical activity over time. A repeated measures multivariate analysis of variance (rmMANOVA) was used to test the change among dietary habits and motivation between baseline and 4-months. A follow-up post-hoc MANOVA was used to determine differences among specific variables per time period. Post-hoc t-tests were used to determine differences among groups per variable. A multivariable linear regression with backwards selection was used to determine the relationship between our dependent variable, body fat percentage, and potential predictors: gender, dairy intake, fat intake, protein, grains, fruits and vegetables, discretionary choices, healthy behaviors, autonomous 
motivation, controlled motivation and amotivation. Non-significant predictors were removed from the model $(\mathrm{p}=0.05)$. 


\section{Section III: Results}

Fifty-nine students completed the survey and body composition analysis at baseline, fifty-nine at 4-months, and fifty-three at 8-months follow-up. This represented an overall retention rate of $89.9 \%$ across two semesters. Approximately $86 \%$ of the participants were Caucasian, 7\% Asian/Pacific Islander, 5\% African American, and 2\% Hispanic. The majority of participants in both the experimental and control group were female. Participants were also of similar age. According to the CDC, a BMI between 18.524.9 is classified as normal or healthy weight (CDC 2017). The experimental participants were within this range at baseline, while control participants were in the overweight range (25.0-29.9) at baseline. See Table 1.

The rmANOVA for body fat percentage was significant between groups from baseline to 4-months $(\mathrm{F}=4.26, \mathrm{df}=55, \mathrm{p}=0.044)$, with a $1.9 \%$ reduction $(27.9 \%-26.77 \%)$ in body fat percentage among the experimental group and a 2.5\% increase (25.25\%-25.89\%) in body fat percentage among the control group. There was no significant difference between groups for knowledge between baseline and 4-months. (Table 4; F=0.002, df=57, $\mathrm{p}=0.966$ ). The rmANOVA for exercise and physical activity was also non-significant $(F=1.845, d f=57 . p=0.180)$. Although not statistically significant, we did see a maintenance of exercise level in the education groups with a reduction in exercise among the control group. See Tables 2, 3, 5. For dietary habits, the rmMANOVA was non-significance $(\mathrm{F}=0.313, \mathrm{df}=49, \mathrm{p}=0.945)$. In addition, the rmMANOVA for motivation was also nonsignificant $(\mathrm{F}=1.882, \mathrm{df}=55, \mathrm{p}=0.143)$. The multivariable linear regression model showed a linear relationship between our outcomes variable, percent fat, and our predictors (Adjusted R-Square $=10.126, \mathrm{df}=5, \mathrm{p}<0.0001$ ). Results indicated that autonomous 
motivation ( $\mathrm{B}=-0.331, \mathrm{p}=0.001)$, controlled motivation $(\mathrm{B}=0.280$, $\mathrm{p}=0.025)$, dairy consumption ( $\mathrm{B}=-0.292, \mathrm{p}=0.004)$, knowledge $(\mathrm{B}=0.174, \mathrm{p}=0.076)$, discretionary choices $(\mathrm{B}=0.275, \mathrm{p}=0.004)$ and gender $(\mathrm{B}=0.532, \mathrm{p}=0.000)$ may explain changes in body fat percentage among college-aged students over time, with autonomous decreasing body fat percentage and the other predictors increasing body fat percentage (Table 9).

At the 8-month follow-up, a t-test indicated percent fat and motivation were nonsignificant between groups (Table 11). There was no difference between groups for knowledge $(\mathrm{t}=1.756, \mathrm{df}=51, \mathrm{p}=0.085)$. The MANOVAs for dietary habits $(\mathrm{F}=0.644, \mathrm{df}=44$, $\mathrm{p}=0.717)$ and motivation $(\mathrm{F}=2.381, \mathrm{df}=3, \mathrm{p}=0.081)$ were non-significant. The multivariable linear regression model showed a linear relationship between our outcomes variable, percent fat, and our predictors at 8-months (Adjusted R-Square=16.485, $\mathrm{df}=49, \mathrm{p}=0.000$ ). Results indicated that discretionary choices $(B=0.192, p=0.068)$, fat intake $(B=0.213$, $\mathrm{p}=0.043$ ) and gender $(\mathrm{B}=0.619, \mathrm{p}<0.0001)$ were the strongest predictors of percent body fat. 


\section{$\underline{\text { Section IV: Discussion }}$}

There are several factors that influence weight-related behavior; however, studies have found that a basic understanding of nutrition is necessary for a diet change to occur (Yahia et al. 2016). We found that a one-semester nutrition course reduced body fat percentage among undergraduate students. Although we were not able to determine exactly how the course impacted percent body fat, we did see a maintained level of exercise in the education group and a decrease in the control group at the end of the semester. This suggests that nutrition knowledge may have influenced body fat percentage through exercise.

One factor that may influence dietary changes in college students is motivation. Autonomous motivation has been consistently associated with maintained behavior change (Williams et al. 1996). Based on our linear regression model for the experimental and control groups at the end of the semester, we found that autonomous motivation is related to a decrease in percent body fat, while controlled motivation resulted in an increase in percent body fat. This suggests that motivation may impact body fat percentage among college students.

Interestingly, from baseline to 4-months, both the experimental and control groups reported a decrease in consumption of dairy, grains, fruits and vegetables, and protein. The experimental group also had no change in fat intake from baseline to 4-months, while the control group increased fat intake. Our study is consistent with previous research which found that students who consumed less than 35\% of daily calories from fat had a higher nutrition knowledge score (Yahia et al., 2016). Although there was not a statistically significant difference in knowledge among groups at 4 months, it is likely that the semester- 
long course played some role in increasing knowledge and decreasing percent body fat among students. Also, due to small sample size, power may have been too low to detect the relationship between the course and knowledge.

We found the effect of education did not have long-term effects on students. At the 8-month time point, there were no significant differences between control and experimental groups among variables. Data from the linear regression model at 8-months suggests that dietary fat and discretionary choices may be significant predictors of body fat percentage among college-aged students. An explanation for this could be that the final data collection (8-months) was two weeks before exam periods, thus students may not have been making healthy dietary choices due to convenience and lack of time. This is consistent with previous research which has found that greater consumption of soda, frozen meals, and fast food was observed during times of stress (Errisuriz et al., 2016). Our results suggest continued nutrition education or refreshers may help students to maintain healthy behaviors.

This study had several limitations. One limitation is that the dietary habits and physical activity survey was not validated, though questions came from validated surveys. Subjects were also recruited on a voluntary basis. It is likely that those who participated, especially in the control group, were already interested in changing their dietary habits. As evidenced by the reduction in percent body fat from baseline to the end of the educational treatment, it is likely the education treatment had some impact on participants, yet we were not able to identify the exact mechanism. It is possible that low power or that variables outside of those measured by the survey may have impacted percent body fat in the experimental group. Furthermore, the method of summation for knowledge and motivation 
may have washed out the ability to detect where differences existed between the control and experimental group.

Our study concludes that nutrition education has the potential to impact body fat percentage among college-aged students. Based on these findings, education interventions to reduce obesity and promote healthy habits among college students should aim to influence motivation, dairy consumption, knowledge, discretionary choices, dietary fat intake and exercise. Our findings indication that one semester of nutrition education alone may not be effective in promoting long-term healthy behaviors. 
Appendix: Tables

Table 1. Demographics of Study Population at Baseline $(\mathbf{n}=59)$

\begin{tabular}{lcc}
\hline & Experimental $(\mathrm{n}=33)$ & Control $(\mathrm{n}=26)$ \\
\hline Age $(\mathrm{yrs})$ & $19.65+1.05$ & $20.88+1.22$ \\
\hline Gender & & \\
\hline Male & 4 & 16 \\
\hline Female & 29 & \\
\hline Race & & $92 \%$ \\
\hline Caucasian & $82 \%$ & $4 \%$ \\
\hline African American & $6 \%$ & $4 \%$ \\
\hline Hispanic & $0 \%$ & $0 \%$ \\
\hline Asian/Pacific Islander & $12 \%$ & \\
\hline Body Composition & & $25.3(\mathrm{SD} 10.5)$ \\
\hline Percent Fat & $27.3(\mathrm{SD} 7.8)$ & $153.9(\mathrm{SD} 29.8)$ \\
\hline Body Mass (lbs) & 139.7 (SD 22.2) & 26.8 (SD6.3) \\
\hline BMI & 23.8 (SD3.15) &
\end{tabular}

Table 2. Descriptive Statistics at Baseline

Variable

\begin{tabular}{|c|c|c|}
\hline & Experimental $(n=33)$ & Control $(n=26)$ \\
\hline Knowledge & 3.03 (SD 0.4667) & 2.46 (SD 0.859) \\
\hline \multicolumn{3}{|l|}{ Motivation } \\
\hline Autonomous & 5.505 (SD 0.235) & 5.340 (SD 0.264) \\
\hline Controlled & 3.434 (SD 0.216) & 3.744 (SD 0.244) \\
\hline Amotivation & 2.192 (SD 0.189) & 2.513 (SD 0.213) \\
\hline \multicolumn{3}{|l|}{ Dietary Habits } \\
\hline Dairy & 15.38 (SD 0.859) & $15.00(\mathrm{SD} 0.971)$ \\
\hline Grains & 21.41 (SD 0.889) & $21.04(\mathrm{SD} 1.006)$ \\
\hline Fruits/Vegetables & 12.94 (SD 0.549) & $12.56(\mathrm{SD} 0.586)$ \\
\hline Protein & 5.13 (SD 0.306) & $5.68(0.346)$ \\
\hline Fat & 16.09 (SD 0.427) & 15.64 (SD 0.483) \\
\hline Discretionary Choices & 9.47 (SD 0.410) & 9.76 (SD 0.464) \\
\hline Healthy Behaviors & 7.23 (SD 0.340) & 7.36 (SD 0.384) \\
\hline Percent Fat & $27.29(\mathrm{SD} 1.56)$ & 25.25 (SD 1.76) \\
\hline Exercise and PA & 4.42 (SD 1.37) & 4.92 (SD 1.65) \\
\hline
\end{tabular}


Table 3. Descriptive Statistics at 4-months

\begin{tabular}{|c|c|c|}
\hline \multirow[t]{2}{*}{ Variable } & \multicolumn{2}{|c|}{ Mean and Standard Deviation (SD) } \\
\hline & Experimental $(n=33)$ & Control $(n=26)$ \\
\hline Knowledge & 3.42 (SD 0.612) & $2.846(\mathrm{SD} 0.674)$ \\
\hline \multicolumn{3}{|l|}{ Motivation } \\
\hline Autonomous & 5.556 (SD 0.196) & 5.327 (SD 0.221) \\
\hline Controlled & 3.273 (SD 0.215) & 4.006 (SD 0.242) \\
\hline Amotivation & 2.404 (SD 0.192) & 2.538 (SD 0.217) \\
\hline \multicolumn{3}{|l|}{ Dietary Habits } \\
\hline Dairy & 14.91 (SD 0.843) & $14.84(\mathrm{SD} 0.954)$ \\
\hline Grains & 21.25 (SD 0.930) & 20.88 (SD 1.052) \\
\hline Fruits/Vegetables & $12.50(\mathrm{SD} 0.586)$ & $12.20(\mathrm{SD} 0.663)$ \\
\hline Protein & 5.06 (SD 0.292) & $5.60(\mathrm{SD} 0.330)$ \\
\hline Fat & 16.03 (SD 0.493) & $15.76(\mathrm{SD} 0.558)$ \\
\hline Discretionary Choices & 9.63 (SD 0.421) & $9.36(\mathrm{SD} 0.476)$ \\
\hline Healthy Behaviors & 6.44 (SD 0.369) & 7.08 (SD 0.418) \\
\hline Percent Fat & 26.77 (SD 1.58) & $25.89(\mathrm{SD} 1.76)$ \\
\hline Exercise and PA & $4.42(\mathrm{SD} 1.15)$ & 4.30 (SD 1.32) \\
\hline
\end{tabular}

Table 4. rmANOVA-Knowledge

\begin{tabular}{lcccc}
\hline Effect & F-Value & df & Sig. & Power \\
\hline Times & 0.820 & 57 & 0.001 & 0.936 \\
\hline Times*Group & 0.002 & 57 & 0.966 & 0.050 \\
\hline
\end{tabular}

Table 5. rmANOVA-Exercise and PA

\begin{tabular}{lcccc}
\hline Effect & F-Value & df & Sig. & Power \\
\hline Times & 1.845 & 57 & 0.180 & 0.267 \\
\hline Times*Groups & 1.845 & 57 & 0.180 & 0.367 \\
\hline
\end{tabular}

Table 6. rmANOVA-Percent Fat

\begin{tabular}{lcccc}
\hline Effect & F-Value & df & Sig. & Power \\
\hline Times & 0.014 & 57 & 0.906 & 0.052 \\
\hline Times*Group & 4.26 & 55 & $0.044^{*}$ & 0.528 \\
\hline $\mathrm{P}<0.05$ & & & &
\end{tabular}

Table 7. rmMANOVA-Dietary Habits

\begin{tabular}{lcccc}
\hline Effect & F-Value & df & Sig. & Power \\
\hline Between-Subjects & & & & \\
\hline$\quad$ Group & 1013.9 & 49 & 0.540 & 0.332 \\
\hline Within-Subjects & & & & \\
\hline$\quad$ Times & 1.139 & 49 & 0.355 & 0.438 \\
\hline Times*Group & 0.313 & 49 & 0.945 & 0.133 \\
\hline
\end{tabular}


Table 8. rmMANOVA-Motivation

\begin{tabular}{lcccc}
\hline Effect & F-Value & df & Sig. & Power \\
Between-Subjects & & & & \\
\hline$\quad$ Group & 1.996 & 55 & 0.125 & 0.486 \\
\hline Within-Subjects & & & & \\
\hline \multicolumn{1}{c}{ Times } & 0.980 & 55 & 0.767 & 0.120 \\
\hline & 1.882 & 55 & 0.143 & 0.461
\end{tabular}

Times*Groups

Table 9. Multiple Linear Regression. Percent Body Fat and Influential Variables at 4-months

\begin{tabular}{lcc}
\hline Variable & Beta Coefficient & P-Value $(<\mathbf{0 . 0 5})$ \\
\hline Autonomous Motivation & -0.362 & 0.001 \\
\hline Controlled Motivation & 0.253 & 0.012 \\
\hline Dairy Consumption & 0.292 & 0.004 \\
\hline Discretionary Choices & 0.275 & 0.004 \\
\hline Knowledge & 0.174 & 0.076 \\
\hline Gender & 0.532 & 0.000
\end{tabular}

Dependent Variable: Percent Body Fat

(Adjusted R-Square=0.524,F=10.126, $\mathrm{p}<0.0001$ ) 
Table 10. Descriptive Statistics at 8-months

Variable

Mean and Standard Deviation (SD)

Experimental $(\mathbf{n}=30)$

Control (n=23)

Knowledge

3.20 (SD 0.081)

2.83 (SD 0.072)

Percent Fat

26.4 (SEM 8.7)

23.9 (SEM 10.6)

Exercise and PA

4.28 (SEM 1.10)

4.43 (SEM 1.3)

Dietary Habits

\begin{tabular}{lcc}
\hline Dairy & 15.28 (SEM .824) & 15.91 (SEM .93) \\
\hline Grains & 19.97 (SEM .85) & 21.13 (SEM .96) \\
\hline Protein & 4.62 (SEM .33) & 5.44 (SEM .37) \\
\hline Fruits/Vegetables & 12.31 (SEM .50) & 12.48 (SEM .56) \\
\hline Fat & 15.55 (SEM .42) & $15.39($ SEM .48) \\
Discretionary & 9.76 (SEM.46) & $9.70($ SEM .51) \\
Choices & & \\
\hline
\end{tabular}

\section{Motivation}

\begin{tabular}{lcc}
\hline Autonomous & 5.79 (SEM .22) & 5.26 (SEM .25) \\
\hline Controlled & 3.43 (SEM .25) & 3.8 (SEM .28) \\
\hline Amotivation & 2.09 (SEM .20) & 2.70 (SEM .22)
\end{tabular}

Table 11. T-Test for Knowledge, Percent Fat, and Exercise and PA

\begin{tabular}{lccc}
\hline \multicolumn{1}{c}{ Variable } & $\mathrm{t}$-Value & $\mathrm{df}$ & Sig. \\
\hline Knowledge & 1.756 & 51 & 0.085 \\
\hline Percent Fat & 0.921 & 51 & 0.342 \\
\hline Exercise and PA & 0.003 & 51 & 0.960 \\
\hline
\end{tabular}

Table 12. MANOVA of Motivation

\begin{tabular}{lccc}
\hline Effect & F-Value & df & Sig \\
\hline Intercept & 714.156 & 49 & 0.000 \\
\hline Group & 2.381 & 49 & 0.081 \\
\hline
\end{tabular}

Table 13. MANOVA of Dietary Habits

\begin{tabular}{lccc}
\hline Effect & F-Value & df & Sig. \\
\hline Intercept & 937.697 & 44 & 0.000 \\
\hline Group & 0.644 & 44 & 0.717
\end{tabular}


Table 14. Multiple Linear Regression Model at 8-months

\begin{tabular}{lcc}
\multicolumn{1}{c}{ Variable } & Beta-Coefficient & P-Value \\
\hline Fat Intake & 0.213 & 0.043 \\
\hline Discretionary Choices & 0.192 & 0.068 \\
\hline Gender & 0.619 & 0.000 \\
\hline
\end{tabular}

Dependent Variable: Percent Fat

(Adjusted R-Square=0.477, $\mathrm{F}=16.485$, $\mathrm{p}<0.001$ ) 


\section{References}

Nelson, M., Kocos, R., Lytle, L., Perry, C. Understanding the Perceived Determinants of Weight-related Behaviors in Late Adolescence: A Qualitative Analysis among College Youth. Journal of Nutrition Education and Behavior. 2009. 41; 287-292.

Pei Lin, L., and Wan Dali Wan Putri, E. The Impact of Nutrition Education Interventions on the Dietary Habits of College Students in Developed Nations: A Brief Review. Malays J Med Sci. 2012. 19(1): 4-14.

Clusky, M., and Grobe, D. College Weight Gain and Behavior Transitions: Male and Female Differences. Journal of the Academy of Nutrition and Dietetics. 2009. 109 (2): 325-329.

De Vos, P., Hanck, C., Neisingh, M., Prak, D., Groen, H., Faas, M. Weight gain in freshman college students and perceived health. Preventative Medicine Reports. 2015. 2; 229-234.

American College Health Association. American College Health Association National Health Assessment Spring 2006 Reference Group data report (abridged). $J$ Am College Health. 2007. 55:195-206.

Liu, Pengju, Ma, Fang., Lou, Huiping., Liu, YanPing. The utility of fat mass index vs body mass index and percentage of body fat in the screening of metabolic syndrome. BMC Public Health. 2013. 13: 629.

Mokdad AH, Bowman BA, Ford ES, Vinicor F, Marks JS, Koplan JP: The continuing epidemics of obesity and diabetes in the United States. JAMA. 2001, 286: 1195-1200. 10.1001/jama.286.10.1195.

Small, M., Bailey-Davis, L., Morgan, N., Maggs, J. Changes in Eating and Physical Activity Behaviors Across Seven Semester of College: Living On or Off Campus Matters. Adolescent Health. 2012. 40(4): 435-441.

U.S. Department of Health and Human Services and U.S. Department of Agriculture. 2015 - 2020 Dietary Guidelines for Americans. $8^{\text {th }}$ Edition. December 2015. Available at http://health.gov/dietaryguidelines/2015/guidelines/.

Gonzales, R., Laurent, J., Johnson, R. Relationship between meal plan, dietary intake, body mass index and appetite responsiveness in college students. Journal of Pediatric Health Care. 31 (3); 320-326.

Downes, Loureen. Physical Activity and Dietary Habits of College Students. The Journal for Nurse Practitioners. 2015. 11 (2); 192-198. 
Racette, S., Deusinger, S., Strube, M., Highstein, G., Deusinger, R. Weight changes, Exercise, and Deitary Patterns during freshman and sophomore years of college. Journal of American College Health. 2005. 53 (6): 245-251.

Tam, R., Yassa, B., Parker, H., O’Connor, H., Allman-Farinelli, M. University students' on-campus food purchasing behaviors, preferences, and opinions on food availability. Nutrition. 2017. 37; 7-13.

Poddar, K., Hosig, K., Nickols-Richardson, S., Anderson, E., Herbert, W., Duncan, S. Low-fat Dairy Intake and Body Weight and Composition Changes in College Students. Journal of the American Dietetics Association. 2009. 109 (8); 1433-1438.

Centers for Disease Control and Prevention. 2017. Healthy Weight. Retrieved from https://www.cdc.gov/healthyweight/assessing/bmi/adult_bmi/index.html

Klodinsky, J., Harvey-Berino, J., Berlin, L., Johnson, R., Reynolds, T. Knowledge of current dietary guidelines and food choice by college students: better eaters have higher knowledge of dietary guidance. Journal of the American Dietetic Association. 107 (8); 1409-1413.

Errisuriz, V., Pasch, K., Perry, C. Perceived stress and dietary choices: The moderating roll of stress management. Eating Behaviors. 2016. 22; 211-216. 
VITA

Emily Ashton, RDN, LD

Education:

- Bachelor's of Science in Human Nutrition

University of Kentucky- Lexington, KY

December 2013

- $\quad$ Dietetic Internship

California Polytechnic State University, SLO- San Luis Obispo, CA

June 2017

- Master's of Science in Nutrition and Food Systems (expected)

University of Kentucky-Lexington, KY

December 2017

Professional Positions Held:

- Annual Meeting Chair

Kentucky Academy of Nutrition and Dietetics

2015-2016

- Teaching Assistant

University of Kentucky- Lexington, KY

2015-present

Professional Memberships:

- Bluegrass Academy of Nutrition and Dietetics

2015-present

- Coastal Tri-Counties Academy of Nutrition and Dietetics 2016-2017

- Academy of Nutrition and Dietetics

2015-present 